\title{
The Effects of Kindness in Saadi's Bustan
}

\author{
Nasrin Mozaffari \\ Bushehr University of Medical Sciences, Bushehr, Iran \\ Faranak Siyanat \\ Bushehr University of Farhangian, Bushehr, Iran \\ Mina Khubanian \\ Bushehr University of Farhangian, Bushehr, Iran \\ Ali Akbar Khansir \\ Bushehr University of Medical Sciences, Bushehr, Iran
}

\begin{abstract}
This study intends to highlight the effects of kindness in one of the best literature and poetry books called "Bustan" in the world. Every poetry is a model of culture and civilization to the human world. Persian literature is one of the richest literatures over the world. Persian poetry is one of the most fruitful branches of the world literature in the area of aphorism. One of the main topics of aphorism is about kindness which is typified in its greatest mood in Saadi's Bustan. Kindness and love are good ethos which has been recommended to man in all of the moral Scriptures. Understanding the effects of kindness is the least thing a man can do to foster a spirit of love in him and others. Therefore, choosing this book, "Bustan", which is full of the effects of kindness, is one of the best choices. The main aim of this article is to investigate the effects of kindness from Saadi's viewpoint in "Bustan,".
\end{abstract}

Index Terms - Saadi, Bustan, advice, kindness, love, poetry

\section{INTRODUCTION}

The fundamental claim of poetry is that poetry represents human culture. Poetry is one of the largest sources of human inspiration.

Khansir and Pakdel (2016) mentioned that in general, poetry is divided into three categories as follows:

1. Lyric poetry can be utilized by expressing the emotion and thoughts of a person and thus, it is short and subjective.

2. Narrative poetry can be utilized by telling a story.

3. Dramatic poetry can be utilized by employing dramatic form or technique.

It has been anticipated that poetry attract attention and interest of all concerned who would like poets and their poems as one of the most important language factors in human society. As a matter of fact, poetry is a matter of pleasure for all concerned that poem of poet has been understand its best in order to make the effect of kindness as specific and comprehensive as possible. However, the language poetry influence can thus be an example of a more intense use of language (Khansir, 2012). Language of poetry is perpetuity of any culture and poetry is almost as old as the nation of each community. There are several written records of national poetry in the history of human being.

Another indication that poetry has been usually accepted as the language of social movements of a country. On the other hand, several movements have been launched in the world have utilized the language poetry to make form the goals. It is usually acknowledged that poetry language can be used as a tool of human motivation; it plays a vital role in human development. The nationalist leaders and kings have seen poetry language as the language of social movement in order to form national slogan during the freedom struggle for independence.

Saadi is one of the greatest poets of Iran and Saadi was born in Shiraz city in the medieval period. He is famous as 'Saadi Shirazi' among Iranian people. He passed his academic works at Baghdad University (Nizamiyya University). The main books of Saadi are Bustan and Gulistan. They are written in verse and prose. One of the famous works has been translated into English Language by Richard Jeffery Newman as follows:

All men and women are to each other

The limbs of a single body, each of us drawn

From life's shimmering essence, God's perfect pearl;

and when this life we share wounds one of us,

all share the hurt as if it were our own.

You, who will not feel another's pain,

You forfeit the right to be called human (Wikipedia 2018).

In this work, Saadi encouraged and promoted respect for human rights without any distinction as to language, race, gender, religion and even culture. 
Shiraz is one of the most ancient cities of Iran and it was the national capital of Iran, since 1334. Thus, the language of Shiraz is Persian language. The tomb of Saddi is in Shiraz. The numbers of national and international tourists visit the tomb of Saddi (as one of the greatest human heritages in the literature of the world) in and out of Iran every year.

As we have been arguing, Persian language is the official language in Iran. Khansir and Mozafari (2014) argued that Persian language is directly appertained to Indo-European language and this language was shifted from Aryans group as the first group which came to Persia location from western Asia. Persian language is one of the beautiful languages over the world and it helps the world literatures for several centuries. Many Iranian great poets appeared in the history of human being are respected by the world great scholars in literature and their works have been translated into several official languages over the world such as English, Germany, Indian languages, American and African languages and Arabic language and etc. In addition, Persian literature is a prosperous treasure of life's pieces of advice and lessons. The pieces of advice which each glimpse of them is required a long life, devotion to great men, and long journey and etc. The pieces of advice have been passed by the great poets for us in the form of delightful and adorable anecdotes and poems.

Thus, one of the most powerful preaching poets is Saddi Shirazi. His recommendation is appreciated in all human societies. Dabiri (2001, p. 24) mentioned that Saddi's recommendations is not only subject to Persian and Arab Muslims, but also Jewish, Christian and others". One of the unique heritages of Iranian literature is Saadi's Bustan book. It was written by Saadi Shirazi. In this book, he used his benefits of magical words to compose his recommendations and advises. His book is accepted by old and new generation. The users of this book are not appertained to any specific time and place, too. That's why everyone in every place and time can use the concepts of humanity in this book which is full of kindness and affection. Therefore, the kindness and affection are the main basic poems of many Iranian great poets such as Firdausi and then he liked Saddi show the goal of his city. However, to introduce his Utopia, Firdausi, too, reviewed the mythic-heroic periods and drew his readers' attention step by step, he described the elements and theme of kindness, introduced the people who are full of righteous to both motivate the readers and activate their capacities and talents to have identities and look for justice ( Talabi, 2009). Saadi believes that an immortal person is the one who has good characters and ethical virtues. He, then, describes the vices and virtues ethics of man. He argues that man should his outward appearance and inner nature portrayed to kindness and leaves injustice and tyranny and immorality from the museum of the world and lights the flame of kindness in order to destroy the darkness from the world. Shamisa (2003) argued that Saadi is a poet, but he had to preach in "Bustan book". Hence, every time, he got a good opportunity, tried to compensate the loss of what he followed. However, without any patient, he tried to compose pieces of advice in poetic style.

To provide a more comprehensive view of this study we investigate the following issues:

1) What are the effects of kindness and love in Saadi's point of view?

2) Which manifestations of kindness does Saadi have more emphasis on life? Why?

3) What is Saadi's main purpose of expressing advice by focusing on kindness?

In what follows, we discuss the Bustan and its poet, effects of kindness, cheerfulness and kindness, hospitality, Kindness and Magnanimity with People, compassion, gratitude, sacrifice and end by describing Bounty and generosity .

\section{BUSTAN AND ITS POET}

Saadi was born and grew up in city of Shiraz in Iran and spent the early primary of his education in this city. He went to Baghdad to continue his studying in Iraq. After completing his theological and educational studies in Baghdad, Saadi began to start his trips and stepped on the way that helped him become a great person with long historical reputation. "In the city of Nezamiyeh, Saadi met many great literati, including Shahab al-Din Abuhafz Omare -Suhrawardi, AbulFaraj e-bin el-Jvzy and Sheikh Safi El-din Ardebili (Foroughi, 2004). Rezaei (2006) argued that Saadi was very busy and hard worker and liked to travel around the world in order to visit other people and get more experience and knowledge. Therefore, he started his long trip from Sham, Hijaz and Lebanon. Based on the speaking of Saadi, he got knowledge from different places. Safa (2013) mentioned that the journey of Saddi started from the years 620 or 621 and ended his journey back to the year 655 while returning to Shiraz. When he came back to Shiraz, he was one of the close persons to the Sa'd ibn Abu Bakr ben Saaied Zangi. Safa (2013) added that although he was selected as a closed person to the kings of Saljoughi Dynasty and some great men of the time, he never became a court poet. He lived in freedom and tried to advise and serve people. His works which have been translated into several languages of the world are proves of intelligence and talent. Safa (2013) argued that Saadi's reputation is the result of his several properties: first, he used his eloquent and miraculous language not only to praise and express romantic feelings but also to serve humans' welfare.

His works which have been translated into several languages of the world are proves of his intelligence and talent. Saadi's reputation is the result of his several properties: First, he used his eloquent and miraculous language not only to praise and express romantic feelings but also to serve humans' welfare. Second, he was a veteran writer and poet and he got to experience the ups and downs of life. Third, he expressed his delicate words by melodious proverbs and stories. Fourth, he made a new form in eulogium and sonnet. Fifth, although he was preaching, advising, and guiding people, Saadi was a witty, humorous and licorice poet. Saadi's works has been divided in two categories: verse and prose. Safa (2013, p. 107) argued that "on the top of his poetic works, there is one of the uncontested masterpieces of Persian poetry 
which had been called Saadi's Koliyat in the old version, but later it was known as Saadi's Bustan". Therefore, Saadi has never called the name of this book "Bustan", but his friends called the name of this Masnavi book "Bustan" (Masnavi is long poem with rhymed couplets). In addition, in some sources, this book is called Saadi Name or Saadi's letters (Hassan, 2011). No one knows when Saadi started writing this book but it has been completed in the year 655 (AH). This book is written about the issues of ethics, training and advice, and it has ten chapters, namely, justice, mercy, love, humility, contentment, devotions, Education, gratitude, repentance, and praying. What is remarkable here is that Saadi completed this book, before; he came back to Shiraz (his home).

Thus, Saadi was master of literary writing and sweetness of expression. Because, he expresses the concepts and meanings along with fine stories and parables. Besides, the concepts and meanings have been mostly used in "Bustan". Saadi's eloquence and attractive speech should not be ignored in this great work. (Yousefi) 2011 mentioned that the language of "Bustan" is so simple and fluent that not only the components such as vocabularies are like the words of prose, but also in many cases the poem itself remains as harmonious as prose. That is, by changing the position of the same component, the verse comes in the form of prose.

In fact, if we as literature experts consider the causes of the effective influence of Saadi's "Bustan"; we will notice that the basic issue of the effective influence of Saadi's Bustan is that Saadi expresses his own lofty ideas through pleasant anecdotes and so that this issue, Saadi's ideas and stories have been always used affectively by the readers in all time. "Bustan" is full of lessons and bywords. The lessons have been mentioned by Saadi in "Bustan" in order to help people find the straightway and make repent. However, we can see that in this book, Saadi gives promise of penitence and argues that if one repents sincerely and God will accept his repentance. Soleimanizadeh (2011) argued that one of the most important of literary works shows utopian beautifully is Saadi's Bustan. This book is a wonderful gift to the people in all time.

"Bustan" is a sign of goodness and importance and the excellence of Saadi's Bustan is manifest. Saadi performed his duty well in Bustan. He refrained from obscene words in his book. He tried to show his romantic world well. In other words, Saadi's wishes, favorites and Utopia were manifested in "Bustan" more than his other works. Shamisa (2003) mentioned that Bustan" is versified artificially and recognized by the great literature experts as a humanistic book. "Bustan "is the most moral Masnavi book (Masnavi is long poem with rhymed couplets) in Persian literature. It seems that it is so simple so many scholars have not pay attention deeply to its artistic structure. This book consists of the greatest examples of imagery and expression.

\section{EFFECTS OF KINDNESS}

Good morality is not pertained to the specific period of time and place. However, human being should pay special attention to humanity in all circumstances and the humanity helps him to be remembered for ever. The affection of human beings toward one another sweetness the world. The action of kindness to people and yourself is sign of good morality that it is very common in many societies. (This paper cannot pretend to examine all kindnesses are common in all societies). In general, people cannot continue their life without the action of kindness and the human societies are agreed to accept kindness and humanity. However, without kindness for man, it is difficult to have a good life. It is obvious that kindness and affection are praised and admired by all people but kindness should be proved by the action of it. Proving this kindness will not be an easy task and it is needed to recognize the manifestations of the kindness. Advice is one of the issues as old as the human being itself. The recommendation of having good behavior and acting properly are very difficult, but they serve the opportunities for wise actions. They will also attract the readers to choose the desired direction of behavior (Yousefi, 2013).

In the history of human being, the Iranian great poets and writers appeared representing the values and effects of kindness and affection in order to attract their audience to this important aspect of human. We add that what is remarkable for us is that Iran has been placed of the great poets and writers blessing the human literature for centuries. We turn now to factors of kindness in the history of Iranian literature directed related to our discussion in this paper. Based on kindness, in Iran, Iranian had tried to help the war prisoners and the poor people and save somebody's life. In addition, they loved other nations and had good relationship with them and resolved the problems through negotiation. They are the outcome of kindness have also been found to relate to Saadi's Bustan as the heritage of humanity is available in and outside of Iran. Yousefi (2013) argued that undoubtedly, kindness and love are the basic of the good deeds which each contains different actions and effects. For example, Khajeh-Nizam al-Mulk Tusi reported in his book," Politics" about moral virtues; he added good qualities such as modesty, goodness, meekness, forgiveness, humility, generosity, truth, patience, mercy, knowledge, wisdom, justice (Yousefi (2013).

What can be said from kindness is that kindness can be made of preaching. Just we face with this point; one can guide people toward the discussion about kindness and love, when people escape from listening and attending to advice, how one can explain about the effects of kindness and love to encourage them to emblazon their pure souls with their good qualities. In fact, Saadi is the great poet who could solve this problem and answered the above question. For these reasons, his outstanding ability earned him the nickname as one of the greatest human poets in the history of human being. One of the characteristics of Saadi's ingenuity is that he teaches morality from his own minor life incidents. Saadi is a moral teacher and has moral thoughts. He studied people's habits, morals and actions then presented the results of the studies through moral messages in his writings (Soleimanizadeh, 2011). He skillfully expressed subtle moral points 
in the form of anecdotes and analogies. In other words, Saadi is recognized as the great eloquent for helping the human society through spirituality. Saadi appreciates kindness and considers this valuable element as a spirit in human's life. He shows the boundaries of kindness among people clearly. Those who live together and love each other kindly are gentler. Here are some important examples of kindness and friendship from Saadi's point of views: Cheerfulness and kindness, hospitality, kindness and goodness to people, etc.

\section{CHEERFULNESS AND KINDNESS}

Cheerfulness has vital place in the human culture. But let us remember mankind follows cheerfulness and kindness that were also written by the great scholars and poets such as Saadi, so Saadi encourages people toward cheerfulness and kindness in his writing. On the other hand, one of the signs of kindness and love is cheerfulness and sociable in "Bustan". Hostility is always one of the condemned human traits which have negative reflected effects on both sides. It is means that both sides (hostility) face with the same disaster. Based on this paragraph, Farzanfar (1990) composed the following poem:

By being cheerful and kind in life

You can keep going to become gleeful at last.

Nafisi (1992) composed a poem as follows:

Anyone who tries to bother people

He will be punished the same as his bad effort.

Saadi always attempts to describe the role of kindness and cheerfulness in all his works, the readers of his books can be imagined the ring of truth in his works. In the third chapter of his "Gulistan book", thus; he also shows the role of refreshing and smiling face as signs of kindness and cheerfulness. Foroughi (2004) mentioned that he also suggests that people should have cheerfulness to the family, friends, the poor, guests, and customers ... in every part of his book.

Yousefi (2014) composed a poem as follows:

Bad temperament will lead men to the hell

Good ethics comes from heaven.

\section{HospitALITY}

Persian people have good relationship with their guests. They have respected them and they have tried to share their properties with their guests. Iranian people believe that a guest is a gift of God. Hospitality is Iran's cultural heritage came from our ancestors. Let us give an idiom about the above sentence (Hospitality is Iran's cultural heritage came from our ancestors) that is written by the poet Saadi, "If you desire your father's legacy, you should attain your father's learning". In fact, this idiom helps us to understand more about Iranian culture and the role of their ancestors as guidance in Iranian life in the history of Iran, and then we learn from history, Iranian people respect their ancestors. However, hospitality is one of sings of Iranian society and Saadi is pertained to this nation. Hospitality Customs and hosting are two of the most prominent manifestations of affection, because having good relationship with guest, will encourage widespread human relations with others. Saa'di composed a poem as follows:

Eating is forbidden

If the host looked angrily

In this book, Saadi respects guest and tells if a guest comes your house, please go toward him and invites him kindly, because; based on Iranian culture, a guest is a gift of God.

\section{Kindness AND MagnANimity With PEOPLE}

One of the most obvious manifestations of kindness in "Bustan" is magnanimity with people. Saadi has never forgotten his magnanimity toward people in his works in general and "Bustan book" in particular. He, several times, orders people to do good works and says them never to refuse a favor (to do good works). He orders people to perform their duties in the best possible way. Soleimanizadeh (2011) mentioned that in all moral texts, helping those who are poor is something admirable. Man has always been ordered to do it. In Iranian culture, we have followed this point, helping the poor gladness the heart. Saadi learned from this ideology. Saadi is follower of righteous people and he has used every opportunity to show the value and dignity of this action as well. He believes that the goodness will help mankind get the resulted in his salvation. He adds that this goodness will help mankind go to heaven. However, based on Saadi's ideology, kindness and goodness are two precious provisions that mankind will use them in the judgment day. Saadi represents this idiom in accordance with goodness: "do good deeds and forget about them..."

In this book, Saadi composes a poem as follows:

Korah (king) who had a treasure of forty houses was perished

Noushirvan's name remained alive due to his respectability (Azhdari, 2003).

Karimi (2010) argued that good ethics is considered essential in all religions. Imam Ali (PBUH) the first Shia Imam after governing the Muslims' society, he discharged many incompetent commanders and governors from service and replaced them with many competent ones. One of his criteria for choosing suitable commanders and governors were their appropriate moral behaviors. Yousefi (2013) composed two poems as follows: 
Be kind to people/ is better than thousand times praying.

A righteous one never tries to be bad

One who thinks well will never behave badly

One of the distinctive characters of a man is his grace, because if a man is not virtuous and good, he will be as motionless as a wall. Saadi encouraged kindness and charity in "Bustan" book. He believes that just giving advice is not enough. He depicts the results of good and bad actions to the sharp-sighted addressees.

\section{COMPASSION}

In Aryanpur Dictionary (1991), the word 'compassion' means kindness and sympathy. In Saadi's Bustan, the concept of the compassion is repeated several times. It is important for remember is that the concept of the compassion in comparison to the function of concept of kindness, the concept of the compassion is used in more special cases than the concept of kindness. From the literary texts, it is clear that Saadi used the concepts of kindness and love for all. But the notion of compassion is just used for specific groups such as the poor, the needy, and the orphans and like this. Saadi, who grew up as an orphan, he knows the concept of orphan hood, and he expressed his condolences to orphans in the poems:

I know the suffering of an orphan's pains

Because I lost my dad in childhood too

Think about those poor orphans

Be aware of their distressed hearts

Bullying and bad temper are unacceptable traits which have been condemned during all human life history. Saadi considered graciousness as one of the characteristics of competent rulers. He has never forgotten the subordinates' pains. Saadi composes poem in relation to this paragraph as follows:

Don't break the heart of your underlings

Lest, tomorrow, you become an underling yourself

We return to the role of Saadi as a master of speech and as one of the great human poet makes advice to people and he don't make differentiate between poor and rich in his speech. He addressed to the rich, and the rulers like this: Do not harass the defenseless /you will beseech them someday. Thus, Saadi points out to the other group of people who deserve compassion and mercy. He recommends the rulers and the judges to sentence them more justly. These sermons are very functional and need more self-reflection in today's era. They are nothing more than adjudicating the convicts wisely and fairly, and having pity on repentant sinners to promote the culture of forgiveness and the eradication of oppression and hatred. Besides, what we have got more advices from Saadi in his writing, Yousefi (2013) indicted that Naser Khosro as an Iranian great writer and he is closed idea to Saadi' idea in his book (Safer nameh) composes the following poems:

"When you are fierce and angry, try not to be blazing as fire

Since an abstinent person avoids being frantic

Look at the prisoners' conditions

Here may be some innocents among them

\section{GRATITUDE}

One of the special characteristics of kindness which is written in "Bustan" is gratitude. In Iranian culture, gratitude has special place among Iranian people and Saadi, several times, mentions it in his book. Sometimes gratitude is between people and their God and sometimes, it is among persons. However, the notion of the gratitude in relation to God by persons is meaningful and thus, the implication of this gratitude is that the persons thank God. Saadi believes that people should thank God in all life. Because, God's grace is boundless. He emphasizes that people will never forget God's grace. It seems that following God's orders will help the person is closer than the others to his God. Saadi adds that people should thank God, because; God is honorable and glorious and total submission to God's commandments will help us resolve our problems. He mentions that giving thanks God; this in itself is an added blessing. In addition, Iranian people respect this word (gratitude). There is an idiom about gratitude in Iranian culture, "A person who has lived as a guest in a family and is beholden to them." We can see many idioms about gratitude in Iranian society and many Iranian people, sometimes, talk about it. Iranian people believe that person should not break salt holder (gratitude), because; salt holder is as the same as gratitude is respected by the people and they have good idiom about it in Iranian culture such as "that ungrateful man was badmouthing his benefactor." Another idiom in relation to gratitude is "after years of eating at Ali's table, I have become deeply beholden". We can see several sentences in relation to gratitude in "Bustan book".

\section{SACRIFICE}

In Aryanpour dictionary (1991), the word "sacrifice" has its own particular meanings such as self-sacrifice, devotion and giving abnegation. In Iranian culture, we can see many stories, movies, and books focuses on this word and define this word and show the role of sacrifice in Iranian society, thus; many Iranian by giving their lives, they guaranteed their country's independence in the history of this country. However, what is very important for us is that the role of 
sacrifice is still alive in Iranian society. This word has motivated the people to do everything to help other humans and they have tried to not be cruel toward other humans. We can conclude that this word has good place in Iranian culture. In "Bustan book", Saadi, several times, mentions the word of sacrifice and invited people to help other humans. He encourages man gives his everything to help the poor. The fact that some characteristics are inborn and some others are acquired. However, sacrifice's characteristic is inborn and the inherent quality of sacrifice is different from other morality. In other morality, a person can learn from the moral lesson. Perhaps, a person empowers the soul of sacrifice, but what is important remember is that there is always sacrifice in the nature of human. Sometimes, human cannot recognize it and never reveal this secret (his sacrifice). Minoie (1990) said that human should pay attention to good advices, because; the good advices help him reveal his sacrifice. He added that if advices are repeated, they will change the mind of human.

\section{BOUNTY AND GENEROSITY}

Now, we consider the signs of kindness and love from a monetary view point is written by Saadi. So far, we discussed this paper from a spiritual love viewpoint. What is important to remember is that Saadi is a man of action and he wants to inform people that to live respectably, one should denote both his life and properties. What we can understand from Saadi's point of view is that he believes that rich people should not only use their wealth themselves, but also donate it to the poor too. He also indicates that the persons have tried to help people (poor) and the persons have tried to divide their wealth among orphans. The persons, their offenses are pardoned by God in this world and the judgment day. However, Saadi believes that this group of the people is the winning team in their life and what greater delight than all of them succeeds in the God examination. Saadi points out that if you want success in this way, you must work hard and more pay attention to orphans and poor people in society. Humanity is the best thing is introduced in "Bustan". Chopra (2014) indicated that

Saadi says that you try to learn love if you would like love. Saadi again points out that if you want attention and appreciation; learn to show respect and appreciation to others. On the other hand, Saadi never encourage the job of greedy person and refuses love of money. He believes that a greedy doesn't have a good outcome. Saadi says that a greedy person is hungry even if he owns the world, but a contented person is happy with a loaf of bread.

\section{CONCLUSION}

As mentioned above, we investigated several conceptions of kindness and love to determine the role of "Bustan book" as one of the human heritages which was written by Iranian great poet in order to guide people towards humanity. Much of the controversy on the issue of the "Bustan" is concerned with the development of spirituality in human life and its relation to our moral values. However, the worth of our moral values surpasses anything else.

In the history of human being, the great persons have born and changed the life of people and tried to find the straight way to reach their purposes. One of them is the Iranian great poet is known Saadi or Saadi of Shiraz. To summarize to this discussion: we turn now to Iranian literature related to our topic. Iranian literature is one of the richest literatures over the world. This literature has served in this world for centuries. One of the masterpieces of Persian literature is poetry. A history of Persian literature comprises the great poets. Thus, one of the masterpieces of Saadi is "Bustan Book" "Bustan book" which was written by Saadi is also outstanding from a literary point of view. The study of this book has been particularly fruitful for understanding the spirituality in human life and distinguishes between material and spiritual. What can be concluded from this book is that reading this book is spiritually very important for us. Much of us are born with spirituality in our life, we are needed to develop it in our life. This book influences the development of the spiritual skills and the aspects of humanity may be those that are necessary for the perception of the world which shows some right ways contribution to the human life. To be sure, this book reports that goodness will finally triumph over evil. Before leaving our discussion about this nice book, what we conclude from this book is that Saadi encourages the beauty of life and informs people to accept the truth. He believes that human being has power to resolve their problems through kindness and love. In addition, this book is a wonderful gift to the world. What is certain, however, is that this book is the intangible cultural heritage of humanity and the corresponding to human and his kindness in the history of his life. There are many countries that translated this beautiful book into their languages from Persian by the eligible and elite research scholars, authors, translators and writers. The book is truly an international book. In this century, we more need this book. The authors of this paper hope that people all over the world use it.

\section{REFERENCES}

[1] Aryanpur, A. (1991). The English Persian Collegiate Dictionary. Tehran: Amir-Kabir Publications.

[2] Azhdari, K. (2003). The Social Thought in Saadi. Bushehr: Islamic Azad University.

[3] Chopra, D. (2014). The seven spiritual laws of success, Translator. Tehran: Ghatreh press.

[4] Dabiri, M. (2011). Saadi and the United Nations, contained in the Monthly Notices of Hafez, 82 (3), 24-30.

[5] Farzanfar, B. (1990). Speech and Eloquence. Tehran: Khwarizmi press.

[6] Foroughi, M, A. (2004). Golestan. Tehran: Martyrs press.

[7] Hassan Lee, K. (2011). Saadi 'S Nice Tradition", the Literature of the Month, 162 (1), 16-23. 
[8] Karimi, H. (2010). The secret of well-being. Qom: Manshure Vahy press.

[9] Khansir A.A. (2012). Teaching Poetry in the ELT Classroom. International Review of Social Sciences and Humanities, 3 (1), 241-245.

[10] Khansir, A.A., \& Mozafari. (2014). The Impact of Persian Language on Indian Languages. Theory and Practice in Language Studies, 4 (11), 2360-2365.

[11] Khansir, A .A. \& Pakdel, F. (2016). The Role of Phonetics in the Teaching of English Language Poetry. Language in India 16 (3), 263-278.

[12] Minoie, M. (1990). The Naseri’s ethics (Tusi). Tehran: Kharazmi.

[13] Nafisi, S. (1992). The Court Anvari. Tehran: Cyrus press.

[14] Rezaei, Z. (2006). The most famous writers and poets. Tehran: Dorna press.

[15] Saadi Shiraz. (2018). Abio-Muhammad Mushih al -Din bin Abdullah Shiraz. Retrieved 2/4/2008, from Wikipedia. https://en. Wikipedia.org/wiki/Saadi Shiraz.

[16] Safa, Z. (2013). The History of Persian Literature. Tehran: Ferdows press.

[17] Shamisa, C. (2003). Cultural Allusions. Tehran: Ferdows press.

[18] Soleimanizadeh N. (2011). Understanding the votes of morality and education in Saadi's Boustan and Varayny's Marzbannameh through Quranic views. Bushehr: Islamic Azad University.

[19] Talebi, F. (2009). Mythological Stories of Shahnameh. Mashhad: Navand Press.

[20] Yousefi, GH. (2001). In the Hope of Goodness and Beauty (Excerpts of the Saadi's Bustan). Tehran: Sohbat Press.

[21] Yousefi, GH. (2013). An Excerpt from Qaboosnameh. Tehran: Amir-Kabir Publications.

[22] Yousefi, GH. (2014). .Saadi's Buustan. Tehran: Khwarizmi press.

Nasrin Mozafari is an Assistant professor in Persian Language at the Bushehr University of Medical Sciences, Bushehr, Iran. She has completed PhD in Persian Language at the Tehran Payame -Nour University. She has published some books and articles in the field of Persian language.

Faranak Siyanat is working at Bushehr university of farhangian, Bushehr, Iran. She has published articles in the field of English and Persian language.

Mina Khubanian is working at Bushehr university of farhangian, Bushehr, Iran. She has published articles in the field of Persian language.

Ali Akbar Khansir (Corresponding Author) is Associate Professor of English Language Teaching at the Bushehr University of Medical Sciences, Bushehr, Iran. He has completed M.A. in English Language Teaching at Aligarh Muslim University in 2003 and $\mathrm{PhD}$ in English Language Teaching at Mysore University in 2010 in India. He has published more than fifty articles in the field of Applied Linguistics and English Language Teaching in many Journals of English Language Teaching and Linguistics and published many books in the field of Applied Linguistics and English Language Teaching and Linguistics in USA, Germany, and UK. 